\title{
UJI AKTIVITAS ANTIBAKTERI EKSTRAK ETANOL BUNGA KECOMBRANG (Etlingera elatior (Jack) R. M.Sm.) TERHADAP BAKTERI Propionibacterium acnes
}

\author{
Yulistia Budianti Soemarie $^{1)}$, Anita Apriliana ${ }^{2)}$, Achmad Kadri Ansyori ${ }^{3)}$, dan Pipih Purnawati ${ }^{4)}$ \\ ${ }^{1,2,3,4}$ Sekolah Tinggi Ilmu Kesehatan Samarinda \\ Email : yulistiabudianti@ymail.com
}

\begin{abstract}
Acne is one of the skin diseases that disturbs the appearance especially of teenagers. Some types of bacteria that cause acne is Propionibacterium acnes. An alternative natural ingredient that can be used to treat acne is kecombrang flowers (Etlingera elatior (Jack) R.M.Sm.). The purpose of this study was to determine whether the kecombrang ethanol extract has antibacterial activity against the bacteria that caused acne, and to know the effective concentration of the ethanol extract of the kecombrang flower on the bacteria that caused the acne. The research conducted was experimental research. The stages of the study began from the determination of the sample, the manufacture of simplicia powder, extraction of kecombrang flowers using the maceration method, phytochemical screening and antibacterial activity test using the disc diffusion method. The concentrations of extract used in the testing of antibacterial activity were $20 \%, 40 \%, 60 \%$ and $80 \%$. The results showed that the ethanol extract of the kecombrang flower contained secondary metabolites in the form of flavonoids and saponins. The results of the testing of the antibacterial activity showed that the ethanol extract of the kecombrang flowers had a medium activity at a concentration of $80 \%$ against the Propionibacterium acnes bacteria with a inhibition zone of 7,67 $\mathrm{mm}$.
\end{abstract}

Keywords: Kecombrang flowers (Etlingera elatior (Jack) R.M.Sm.), Antibacterial activity test, Propionibacterium acnes

\section{PENDAHULUAN}

Jerawat merupakan penyakit kulit yang terjadi akibat inflamasi kronik pada kelenjar minyak yang menyebabkan bintik-bintik pada kulit wajah, leher, dada dan punggung. Jerawat sering kali menyerang remaja usia belasan tahun, namun banyak juga ditemukan pada orang dewasa dengan usia dua puluh tahun hingga empat puluh tahun (Irianto, 2015).

Timbulnya jerawat disebabkan oleh banyak faktor, baik yang berasal dari luar maupun dari dalam. Faktor-faktor tersebut adalah: faktor hormonal, faktor makanan, faktor kosmetik, faktor kebersihan, dan faktor infeksi. Faktor infeksi di kelenjar minyak terjadi karena adanya peningkatan jumlah dan aktivitas bakteri (Bhate and Williams., 2013). Propionibacterium acnes merupakan salah satu bakteri penyebab jerawat selain Staphylococcus aureus dan Staphylococcus epidermidis. Jenis lain bakteri penyebab jerawat yang ditemukan saat ini adalah Propionibacterium granulosum (Archer, 2006).

Masyarakat biasanya menggunakan senyawa kimia untuk mengobati jerawat, salah satunya menggunakan antibiotik topikal maupun oral. Klindamisin merupakan antibiotik yang sering digunakan masyarakat untuk menangani jerawat. Penyalahgunaan antibiotik akan menyebabkan resistensi bakteri terhadap antibiotik (Bisth et al., 2009).

Bunga kecombrang (Etlingera elatior (Jack) R.M.Sm.) telah dimanfaatkan masyarakat sebagai obat-obatan untuk kanker, tumor dan juga sebagai bahan kosmetik alami seperti bahan pencampur bedak. Suku Baduy dalam memanfaatkan bunga kecombrang sebagai sabun yang digunakan untuk mandi, menggosok gigi, dan keramas (Agustina et $a l ., 2016)$. Zat antibakteri ekstrak etanol dari bunga 
kecombrang dapat menghambat beberapa bakteri seperti Bacillus subtilis, Pseudomonas aeroginosa, Salmonella typhimurium, Escherichia coli, Listeria monocytogenes dan Staphylococcus aureus (Ghasemzadeh et al., 2015). Hasil penelitian lain mengemukakan bahwa antibakteri ekstrak air bunga kecombrang (Etlingera elatior (Jack)R.M.Sm), dengan konsentrasi yang digunakan adalah: 20\%, 40\%, 60\%, 80\% dan 100\%. Ekstrak air bunga kecombrang dengan konsentrasi $20 \%$ sudah mampu menghambat pertumbuhan bakteri Staphylococcus aureus yaitu dengan terbentuknya zona hambat (zona bening) disekitar kertas cakram, sedangkan pada Escherichia coli terhambat pada konsentrasi 60\% (Sukandar et al., 2010). Berdasarkan uraian diatas, maka dilakukan pengujian antibakteri terhadap ekstrak etanol bunga kecombrang (Etlingera elatior (Jack) R.M.Sm.) menggunakan bakteri Propionibacterium acnes dengan melihat adanya aktivitas antibakteri dari ekstrak etanol bunga kecombrang yang ditandai dengan terbentuknya zona bening disekitar kertas cakram.

\section{METODE PENELITIAN}

Alat

Alat yang digunakan pada penelitian ini yaitu maserator, alat-alat gelas, autoklaf, inkubator, rotary evaporator, Laminar airflow cabinet, vortex, dan hotplate.

\section{Bahan}

Bahan yang digunakan untuk penelitian ini yaitu bunga kecombrang, etanol 70\%, air suling, Nutrien Agar, Mueller Hinton Agar (MHA), Klindamisin 1\%, DMSO (dimetil sulfoksida) 1\%, $\mathrm{HCl} 2 \mathrm{~N}$, serbuk $\mathrm{Mg}, \mathrm{FeCl}_{3} 1 \%$, amil alkohol, pereaksi Mayer, pereaksi bouchardat, pereaksi dragendrof.

\section{Sampel}

Ekstrak etanol bunga kecombrang yang digunakan pada penelitian ini dengan konsentrasi $20 \%, 40 \%$, 60\% dan $80 \%$. Kontrol positif yang digunakan adalah klindamisin $1 \%$ dan kontrol negatif yang digunakan adalah DMSO $1 \%$.
Pembuatan Simplisia dari Bunga Kecombrang (Etlingera elatior (Jack) R.M.Sm.)

Bunga kecombrang yang telah dikumpulkan disortasi basah dan sortasi kering. Sortasi basah bertujuan untuk memisahkan bunga kecombrang dari batang bunga kecombrang dan bagian bunga yang sudah kering serta kotoran yang terdapat pada bunga kecombrang dan selanjutnya sampel dirajang tipis dan dikeringkan dengan cara dijemur di bawah sinar matahari secara tidak langsung.

\section{Pembuatan Ekstrak Etanol Bunga Kecombrang}

Pembuatan ekstrak etanol bunga kecombrang dilakukan dengan cara metode maserasi, yaitu simplisia bunga kecombrang sebanyak 250 gram dimaserasi menggunakan etanol 70\% (2500 mL). Ekstrak cair yang diperoleh diuapkan di atas waterbath sampai dihasilkan ekstrak kental.

\section{Skrining Fitokimia Ekstrak Bunga Kecombrang}

Identifikasi golongan senyawa kimia dilakukan pada ekstrak etanol bunga kecombrang yang meliputi uji kandungan alkaloid, flavonoid, tanin dan saponin.

\section{Pengujian Aktivitas Antibakteri Ekstrak Etanol Bunga Kecombrang}

Media yang digunakan pada penelitian ini adalah Nutrient Agar (NA). Konsentrasi ekstrak etanol bunga kecombrang yang dibuat sebesar $20 \%$, $40 \%, 60 \%$ dan $80 \%$ serta kontrol positif Klindamisin $1 \%$ dan kontrol negatif DMSO 1\%. Cakram yang telah dijenuhkan dengan ekstrak etanol bunga kecombrang serta kontrol positif dan negatif diletakkan di atas permukaan media agar yang telah diinokulasi dengan biakan bakteri Propionibacterium acnes. Pengujian dilakukan 3 kali pengulangan pada setiap konsentrasi.

\section{HASIL DAN PEMBAHASAN}

\section{Pembuatan Simplisia dan Ekstrak dari Bunga Kecombrang}

Bunga kecombrang segar yang telah terkumpul sebanyak $3 \mathrm{~kg}$ kemudian disortasi basah dan sortasi kering. Hasil dari pengeringan bunga kecombrang segar yang telah dirajang sebanyak 300 gram. Susut pengeringan simplisia sebesar $10 \%$. Standar susut pengeringan simplisia yang baik tidak lebih dari 10\% (DepKes RI, 2008). 
Ekstraksi dan Skrinning Fitokimia Ekstrak Etanol Bunga Kecombrang

Metode ekstraksi yang digunakan adalah maserasi. Pelarut yang digunakan pada pembuatan ekstrak yaitu etanol 70\%. sebanyak 250 gram simplisia bunga kecombrang dengan etanol $70 \%$ sebanyak 2,5 L, dimana perbandingan sampel dan pelarut adalah 1:10 (Saifuddin, 2014). Ekstrak cair yang diperoleh kemudian di uapkan di atas waterbath hingga diperoleh ekstrak kental berwarna coklat tua. Ekstrak kental yang didapat seberat 28,79 gram sehingga rendemen yang diperoleh sebesar $11,52 \%$. Adapun rumus penetapan rendemen adalah

Rendemen Ekstrak= $\frac{\text { Berat ekstrak }}{\text { Berat serbuk }} \times 100 \%$

Skrining fitokimia dilakukan untuk mengetahui adanya kandungan senyawa metabolit sekunder yang terkandung dalam ekstrak etanol bunga kecombrang. Golongan metabolit sekunder yang akan diperiksa adalah alkaloid, flavonoid, tanin dan saponin. Hasil pengujian skrining fitokimia terhadap ekstrak etanol bunga kecombrang dapat dilihat pada Tabel 1 .

Dari hasil pengujian skrining fitokimia ekstrak etanol bunga kecombrang didapatkan hasil bahwa ekstrak tersebut mengandung metabolit sekunder berupa flavonoid dan saponin. Flavonoid dari ekstrak etanol bunga kecombrang ditunjukkan dengan adanya perubahan warna kuning jingga pada lapisan amil alkohol. Hasil ini diperkuat oleh penelitian Lachumy et al. (2010) yang menunjukkan bahwa dalam ekstrak bunga kecombrang tersebut juga berhasil teridentifikasi kandungan senyawa flavonoid. Ekstrak etanol bunga kecombrang juga diketahui positif mengandung saponin yang ditandai terbentuknya busa setelah pengocokan. Berbeda dengan hasil penelitian Lestari et al. (2014) yang menginformasikan bahwa bunga kecombrang negatif saponin. Hal ini dapat terjadi karena perbedaan tempat tumbuh dan kandungan zat hara dalam tanah yang dapat mempengaruhi kandungan senyawa metabolit sekunder (Salim et al., 2016).

\section{Pengujian Aktivitas Antibakteri Ekstrak Etanol Bunga Kecombrang}

Metode yang digunakan pada pengujian ini adalah metode kertas cakram, pemilihan metode ini didasarkan karena pengerjaannya mudah dilakukan, lebih murah dan tidak memerlukan peralatan khusus (Jawetz, 2007).

Pengujian aktivitas antibakteri ini menggunakan bakteri Propionibacterium acnes. Hasil uji ekstrak etanol bunga kecombrang dengan berbagai konsentrasi dapat dilihat pada Tabel 2

Hasil pengujian didapatkan bahwa pada konsentrasi 20\%, 40\%, 60\% dan $80 \%$, terbentuk zona hambat (zona bening) disekitar kertas cakram dengan hasil rata-rata yang berurutan yaitu $5,83 \mathrm{~mm}$, 6,17 mm, 6, $67 \mathrm{~mm}$ dan 7,67mm dengan kategori aktivitas sedang.

Berdasarkan hasil uji zona hambat yang terbentuk dari ekstrak etanol bunga kecombrang dapat dihubungkan dengan senyawa-senyawa yang terkandung didalamnya. Menurut Lachumy et al. (2010) ekstrak etanol bunga kecombrang mengandung senyawa metabolit sekunder golongan flavonoid dan saponin.

Tabel 1. Hasil skrining fitokimia ekstrak etanol bunga kecombrang (Elingera elatior (Jack) R. M. Sm)

\begin{tabular}{|c|c|c|c|c|}
\hline No & Uji Fitokimia & Reagen & Hasil & Keterangan \\
\hline \multirow{3}{*}{1} & \multirow{3}{*}{ Alkaloid } & Mayer & Endapan putih/kuning & - \\
\hline & & Bouchardat & Larutan coklat hitam & - \\
\hline & & Dragendorf & Endapan merah bata & - \\
\hline 2 & Flavonoid & HCL pekat + Amil alkohol & $\begin{array}{l}\text { Terbentuk lapisan amil } \\
\text { berwarna jingga }\end{array}$ & + \\
\hline 3 & Saponin & $\mathrm{HCl} 2 \mathrm{~N}$ & Terbentuk busa & + \\
\hline 4 & Tanin & $\mathrm{FeCl}_{3} 1 \%$ & Larutan hijau kehitaman & - \\
\hline
\end{tabular}

Keterangan: + : menunjukkan hasil positif $\quad$-: menunjukkan hasil negatif 
Tabel 2. Hasil pengukuran zona hambat bakteri Propionibacterium acnes

\begin{tabular}{cccc}
\hline Bakteri & $\begin{array}{c}\text { Konsentrasi } \\
\text { Sampel }\end{array}$ & $\begin{array}{c}\text { Diameter rata-rata } \\
\text { zona Hambat }(\mathbf{m m})\end{array}$ & $\begin{array}{c}\text { Kriteria daya hambat (David } \\
\text { dan Stout, 1971) }\end{array}$ \\
\hline \multirow{2}{*}{$\begin{array}{c}\text { Propionibacterium } \\
\text { acnes }\end{array}$} & 60 & 7,16 & Sedang \\
& 80 & 7,42 & Sedang \\
& Klindamisin 1\% & 7,52 & Sedang \\
& DMSO 1\% & 9,08 & Sedang \\
& 32,33 & Sangat Kuat \\
& Tidak ada zona & Lemah \\
\hline
\end{tabular}

Berdasarkan uji fitokimia yang dilakukan pada ekstrak etanol bunga kecombrang senyawa metabolit sekunder yang positif terkandung adalah senyawa yang sama. Senyawa flavonoid bekerja menghambat bakteri dengan cara merusak membran sel yang mengakibatkan terhambatnya aktivitas dan biosintesis enzim spesifik yang diperlukan dalam reaksi metabolisme sehingga bakteri tersebut tidak dapat hidup (Maghdalena et al., 2015). Saponin merupakan zat yang dapat berinteraksi dengan sel bakteri menyebabkan dinding sel bakteri menjadi lisis atau pecah sehingga bakteri tidak dapat berkembang biak bahkan mati (Pratiwi, 2008).

Hasil dari pengujian kontrol positif klindamisin terbentuk zona hambat yang paling besar yaitu $36,3 \mathrm{~mm}$ hal ini dikarenakan klindamisin merupakan senyawa murni yang memiliki spektrum luas yang efektif menghambat bakteri gram positif dan gram negatif. Efek klindamisin bersifat bakteriostatik meskipun dalam kadar tinggi bersifat bakterisid terhadap bakteri yang sensitif (Hardjosaputra et al., 2008). Kontrol negatif pada perlakuan menggunakan dimetil sulfoksida (DMSO) tidak terlihat zona hambat. Hal ini terjadi karena dimetil sulfoksida merupakan senyawa organosulfur dan hanya digunakan untuk mengencerkan ekstrak. Cairan ini bersifat tidak toksik sehingga tidak memberikan daya hambat pertumbuhan bakteri dan tidak mengganggu hasil pengamatan aktivitas antibakteri (Pratiwi, 2008).

\section{KESIMPULAN}

1. Ekstrak etanol bunga kecombrang memiliki aktivitas sebagai antibakteri terhadap bakteri Propionibacterium acnes

2. Ekstrak etanol bunga kecombrang dapat menghambat pertumbuhan bakteri Propionibacterium acnes pada konsentrasi $20 \%$ sebesar 5,83 mm, $40 \%$ sebesar $6,17 \mathrm{~mm}, 60 \%$ sebesar 6,67 $\mathrm{mm}$ dan $80 \%$ sebesar 7,67 $\mathrm{mm}$. Berdasarkan hasil uji aktivitas antibakteri kekuatan daya hambat ekstrak etanol bunga kecombrang (Etlingera elatior (Jack)R.M.Sm) pada semua konsentrasi adalah sedang

\section{DAFTAR PUSTAKA}

Agustina, Z.A.,Suharmiati., dan Ipa, M. 2016. Penggunaan kecombrang (Etlingera elatior) sebagai alternatif pengganti sabun dalam perilaku hidup bersih dan sehat suku Baduy". Media Litbangkes: Vol. 26 . Hal: 241-242.

Archer, Pamela. 2006. The complete guide to acne; prevention, treeatment and remedis. eBook Wholesaler Publication. Hal: 16.

Bhate, K dan Williams, H. C. 2013. "Epidemiology of acne vulgaris". British Journal of Dermatology. Vol. 20 (3). Hal: 476-481.

Bisth, R., Katiyar, A., Singh, R., Mittal, P. 2009. "Antibiotic resstence a global issue of concern". Asian Journal of Pharmaceutical and Clinical Research. Vol. 2 (2). Hal: 37-38. 
Depkes RI, 2008. Farmakope herbal Indonesia. Jakarta: Depkes RI Hal: 149.

Ghasemzadeh, A., Jaafar, Hawa, Z. E., Rahmat, A., Ashkani, S. 2015. "Secodary metabolites constituents and antioxidant, anticancer and antibacterial activities of Etlingera elatior (Jack) R. M. Sm. Grown in differnt location of malaysia". BMC Complementary and Alternative Medicine. Vol. 15 (1). Hal: 8-9

Hardjosaputra, P., Purwanto, L., Kemalasari, T., Kurnadi, L., Indriyantoro., Indriyani, N. 2008. Data obat di Indonesia. Edisi 11: Jakarta. Hal: 344-345.

Irianto, Koes. 2015. Memahami berbagai penyakit. Bandung: Penerbit ALFABETA. Hal: 42.

Jawetz, et al. 2007. Mikrobiologi untuk profesi kesehatan. Surabaya: Airlangga University Press. Hal:163-165.

Lachumy, S. J. T., Sasidharan, S., Sumathy, V., Zuraini, Z. 2010. "Phamacological activity, phytochemical analysis and toxicity of metanol ekstrak of etlingera elatior (Torch Ginger) flower". Asian Pasific Journal Of Tropical Medicine. Hal: 772.

Lestari, T., Rahmiyani, I., Munawaroh, S. 2014. "Pengaruh metode dan variasi pelarut ekstraksi terhadap kadar polifenolat bunga kecombrang (Etlingera elatior (Jack0 R. M. Sm)". Jurnal Kesehatan Bakti Husada. Vol. 12 (1). Hal: 91.

Maghdalena, N. V., dan Kusnadi, J. 2015. "Uji aktivitas antibakteri ekstrak kasar daun gambir (uncaria gambir) metode microwaveassisted extraction terhadap bakteri patogen". Jurnal Pangan dan Agroindustri. Vol. 3 (1). Hal: 131.

Pratiwi S.T. 2008. Mikrobiologi farmasi. Erlangga. Jakarta. Hal: 82-84.

Saifudin, A. 2014. Senyawa metabolit sekunder teori, konsep, dan teknik pemurnian. Yogyakarta. Penerbit DeePublish. Hal: 43.

Salim, M., Yahya., Sitorus, H., Ni'mah, T., Marini. 2016. "Hubungan kandungan hara tanah dengan produksi senyawa metabolit sekunder pada tanaman duku (Lansium domesticum
Corr var Duku) dan potensinya sebagai larvasida". Jurnal Vektor Penyakit. Vol. 10 (1) Hal: 15-16.

Sukandar, D., Radiastuti, N., Jayanegara, I., Hudaya, A. 2010. "Karakterisasi senyawa aktif antibakteri ekstrak air bunga kecombrang (Etlingera elatior) sebagai bahan pangan fungsional". Valensi Vol. (2): 333339. 